\title{
Chemistry of 2-(arylazo)phenolate complexes of ruthenium. Synthesis, structure and reactivities
}

\author{
Kanchana Sui ${ }^{a}$, Shie-Ming Peng ${ }^{\mathrm{b}}$, Samaresh Bhattacharya ${ }^{\mathrm{a}, *}$ \\ ${ }^{a}$ Department of Chemistry, Inorganic Chemistry Section, Jadavpur University, Calcutta 700 032, India \\ ${ }^{\mathrm{b}}$ Department of Chemistry, National Taiwan University, Taipei, Taiwan, R.O.C.
}

Received 16 June 1998; accepted 6 August 1998

\begin{abstract}
A group of six ruthenium(III) complexes of type $\left[\mathrm{Ru}(\mathrm{acac})(\mathrm{L})_{2}\right]$, where acac=acetylacetonate anion and $\mathrm{L}=2-(\operatorname{arylazo})-4-$ methylphenolate anion or 1-(phenylazo)-2-naphtholate anion, have been synthesized and characterized. Structural characterization of a representative complex, where $\mathrm{L}=1$-(phenylazo)-2-naphtholate anion, shows that the azophenolate ligands are coordinated as $\mathrm{N}, \mathrm{O}$-donor ligands forming six-membered chelate rings. The complexes are paramagnetic (low-spin $\left.\mathrm{d}^{5}, S=1 / 2\right)$ and show rhombic ESR spectra in 1:1 dichloromethane-toluene solution at $77 \mathrm{~K}$. In carbon tetrachloride solution, these complexes show intense LMCT transitions in the visible region together with weak ligand-field transitions in the near-IR region. All the complexes display two cyclic voltammetric responses, a ruthenium(III)-ruthenium(IV) oxidation in the range of 0.83 to $1.03 \mathrm{~V}$ vs SCE and a ruthenium(III)ruthenium(II) reduction in the range of -0.24 to $-0.52 \mathrm{~V}$ vs SCE. Formal potentials of both the couples correlate linearly with the Hammett constant of the para substituent in the arylazo fragment of the 2-(arylazo)-4-methylphenolate ligand. The ruthenimn(IV) and ruthenium(II) congeners of the $\left[\mathrm{Ru}^{\mathrm{III}}(\mathrm{acac})(\mathrm{L})_{2}\right]$ complexes have been generated by chemical or electrochemical methods and they have been characterized by electronic spectroscopy and cyclic voltammetry. (C) 1999 Elsevier Science Ltd. All rights reserved.
\end{abstract}

Keywords: Ruthenium; 2-(arylazo)phenolates; Synthesis; Structure; Reactivities

\section{Introduction}

The chemistry of ruthenium has been a center of immense interest [1], largely because of the fascinating reactivities exhibited by its complexes. It is the nature of the ligands, which surround the metal, that dictates the properties of the complexes. Coordination of ruthenium by ligands of different types is of significant importance in this respect. In the present work, which has originated from our interest in the chemistry of ruthenium in different coordination environments [2], we have used 2-(arylazo) phenols (1) as the principal ligand. The interest behind the choice of these ligands is two-fold. Firstly, it contains two potential donor sites, viz. azo nitrogen and phenolate oxygen, which are of opposite natures. The azo group has a strong $\pi$-acid character and coordination by azo nitrogen stabilizes ruthenium in the lower oxidation states [3], while phenolate oxygen is a hard base and coordination by it is known to stabilize the higher oxidation states of the same metal [4]. Secondly, these

\footnotetext{
* Corresponding author.
}

ligands display different coordination modes upon complex formation. The 2-(arylazo)phenol ligands are known to coordinate metal ions usually as a bidentate N,Odonor, via dissociation of the phenolic proton, forming a six-membered chelate ring (2) [5]. However, we have recently observed that they also form five-membered chelate ring (3) under sterically forced conditions [6]. These ligands are also known to coordinate metal ions as dianionic tridentate $\mathrm{C}, \mathrm{N}, \mathrm{O}$-donors (4) affording organometallic complexes [7]. It may be mentioned here that the ruthenium chemistry of these ligands has not been much explored [8]. Herein, we have restricted our studies to some bis-2-(arylazo)phenolate complexes of ruthenium, where acetylacetonate anion has served as the coligand. The synthesis of a series of mixed tris complexes, their characterization including structure determination and their reactivities are described in this paper. Six 2-(arylazo)phenols, which are abbreviated in general as HL, where $\mathrm{H}$ stands for dissociable phenolic proton, have been used in the present study. Specific abbreviations are shown in structure 5. In the 2-(arylazo)4-methylphenols, the substituent $\mathrm{R}$ is systematically varied in order to study their influence on the redox properties of the complexes. 


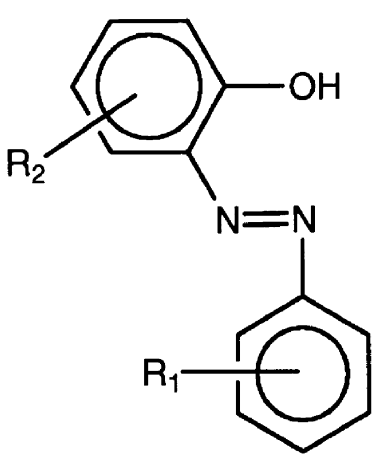

1

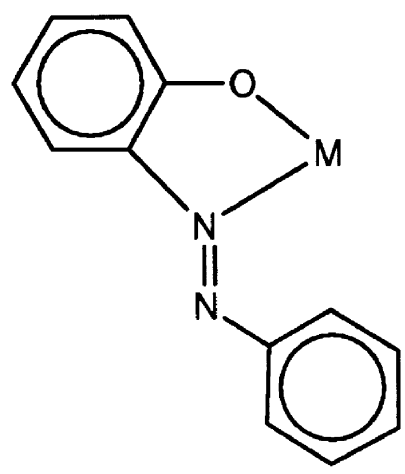

3

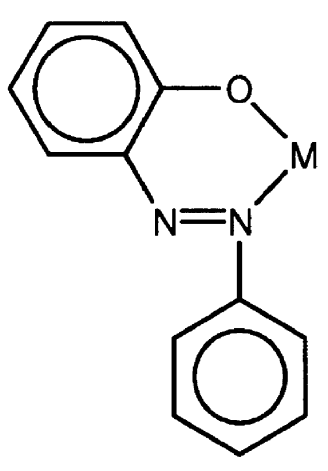

2

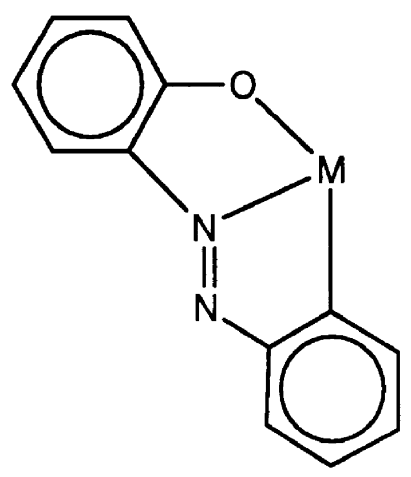

4

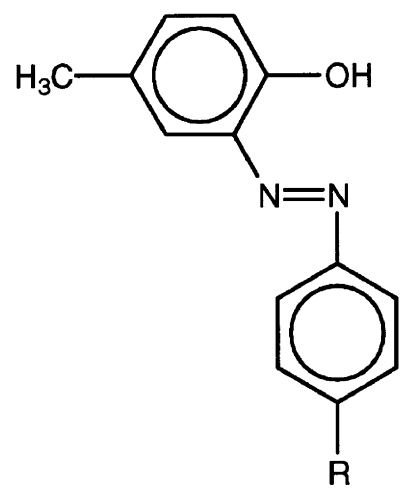

R Ligand

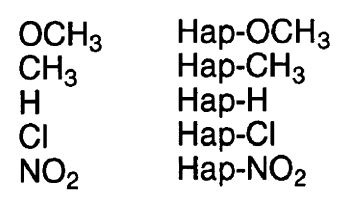




\section{Experimental}

\subsection{Materials}

Commercial ruthenium trichloride, purchased from Arora Matthey, Calcutta, India was converted to $\mathrm{RuCl}_{3} \cdot 3 \mathrm{H}_{2} \mathrm{O}$ by repeated evaporation with concentrated hydrochloric acid. $\left[\mathrm{Ru}(\mathrm{acac})_{3}\right] \quad(\mathrm{acac}=$ acetylacetonate ion) was prepared by following a reported procedure [9]. The 2-(arylazo)phenol ligands were prepared by coupling diazotized anilines with $p$-cresol or $\beta$-naphthol. Purification of acetonitrile and preparation of tetraethylammonium perchlorate for electrochemical work were performed as before [2]. All other chemicals and solvents were reagent grade commercial materials and were used as received.

\subsection{Physical measurements}

Microanalyses $(\mathrm{C}, \mathrm{H}, \mathrm{N})$ were performed using a Perkin-Elmer 240C elemental analyzer. IR spectra were obtained on a Perkin-Elmer 783 spectrometer with samples prepared as KBR pellets. Electronic spectra were recorded on Hitachi U 3501 and Shimadzu UV 240 spectrophotometers. Magnetic susceptibilities were measured using a PAR 155 Vibrating sample magnetometer. Xband ESR spectra were recorded on a Varian E-109C spectrometer fitted with a quartz Dewar for measurements at $77 \mathrm{~K}$ (liquid nitrogen) and the spectra were calibrated with DPPH $(g=2.0037)$. Electrochemical measurements were made using a PAR model 273 Potentiostat. A platinum disc working electrode (of area $0.02 \mathrm{~cm}^{2}$ ), a platinum wire auxiliary electrode and an aqueous saturated calomel reference electrode (SCE) were used in a three electrode configuration. A platinumwire gauge working electrode was used in the coulometric experiments. Dinitrogen gas was purified by successively bubbling it through alkaline dithionite and concentrated sulphuric acid. All electrochemical experiments were performed under a dinitrogen atmosphere and electrochemical data were collected at $298 \mathrm{~K}$ and are uncorrected for junction potentials. A RE $0089 \mathrm{X}-\mathrm{Y}$ recorder was used to trace the voltammograms.

\subsection{Preparations}

The $\left[\mathrm{Ru}(\mathrm{acae})(\mathrm{L})_{2}\right]$ complexes were synthesized following a general procedure. Specific details for one complex are given in next section.

\subsection{1. $\left[\mathrm{Ru}(\mathrm{acac})(\mathrm{ap}-\mathrm{H})_{2}\right]$}

$\left[\mathrm{Ru}(\mathrm{acac})_{3}\right](100 \mathrm{mg}, 0.25 \mathrm{mmol})$ and Hap-H (320 mg, $1.5 \mathrm{mmol}$ ) were taken in $20 \mathrm{~cm}^{3}$ ethylbenzoate. The mixture was heated at $160^{\circ} \mathrm{C}$ with continuous passage of nitrogen to remove the volatile acetylacetone. Heating was continued for $6 \mathrm{~h}$ and the colour of the solution gradually became brown. The solvent was then evaporated under reduced pressure. The crude product was dissolved in hexane and was subjected to chromatography on a silica gel (60-120 mesh) column. On elution with hexane and 2:1 hexane:benzene mixture as eluent, yellow and light red bands came out and were rejected. With a 1:4 hexane:benzene mixture as the next eluent, a deep brown band came out. This was collected and evaporation of the eluate gave $\left[\mathrm{Ru}(\mathrm{acac})(\mathrm{ap}-\mathrm{H})_{2}\right]$ as a dark brown microcrystalline solid. The yield was $65 \%$ (102 mg).

\subsection{2. $\left[R u(a c a c)(a n-H)_{2}\right]$}

$\left[\mathrm{Ru}(\mathrm{acac})(\mathrm{an}-\mathrm{H})_{2}\right]$ was prepared using the same above procedure with slight modification in the purification method. The crude sample was dissolved in a minimum amount of dichloromethane and chromatographed through a silica gel column. Initial yellow and faint red bands, which came out with hexane and a 3:1 hexane: benzene mixture as eluents, were rejected. With 2:1 hexane: benzene as the eluent, a deep brown band came out and was collected. Evaporation of the eluate gave the pure compound. The yield was $68 \%$ (119 mg).

\subsection{Crystallography}

Single crystals of $\left[\mathrm{Ru}(\mathrm{acac})(\mathrm{an}-\mathrm{H})_{2}\right]$ were grown by slow evaporation of a 1:1 acetone-isopropanol solution of the complex. Selected crystal data and data collection parameters are given in Table 1. Data were collected on a Siemens Smart CCD diffractometer using graphitemonochromated Mo-K $\mathrm{K}_{\alpha}$ radiation $(\lambda=0.71073 \AA)$ by $\theta$ $2 \theta$ scans. The standard reflections, used to check the crystal stability towards X-ray exposure, showed no sig-

Table 1

Crystallographic data for $\left[\mathrm{Ru}(\mathrm{acac})(\mathrm{an}-\mathrm{H})_{2}\right]$

\begin{tabular}{ll}
\hline Empirical formula & $\mathrm{C}_{37} \mathrm{H}_{29} \mathrm{~N}_{4} \mathrm{O}_{4} \mathrm{Ru}$ \\
$f_{\mathrm{w}}$ & 694.71 \\
Space group & $\mathrm{P} 2_{1} / \mathrm{n}$ \\
$a(\AA)$ & $11.9623(2)$ \\
$b(\AA)$ & $13.7817(2)$ \\
$c(\AA)$ & $19.5525(3)$ \\
$\alpha\left({ }^{\circ}\right)$ & 90 \\
$\beta\left(\left(^{\circ}\right)\right.$ & $103.474(1)$ \\
$\gamma\left({ }^{\circ}\right)$ & 90 \\
$V\left(\AA^{3}\right)$ & $3134.72(8)$ \\
$Z$ & 4 \\
$\rho_{\text {calc }}\left(\mathrm{mg} \mathrm{m}^{-1}\right)$ & 1.472 \\
$\lambda(\AA)$ & 0.71073 \\
$\mathrm{Crystal} \mathrm{size}(\mathrm{mm})$ & $0.20 \times 0.08 \times 0.05$ \\
$T(\mathrm{~K})$ & $295(2)$ \\
$\mu\left(\mathrm{mm}^{-1}\right)$ & 0.548 \\
$R 1$ & 0.0489 \\
$w R 2$ & 0.0874 \\
$\mathrm{GOF}$ & 1.054
\end{tabular}


nificant intensity variation over the entire course of data collection. X-ray data reduction and structure solution and refinement were done using the NRCVAX package. The structure was refined by full-matrix least-squares on $F^{2}$. Final cycles of refinement converged with discrepancy indices of $R 1=0.0489$ and $w R 2=0.0874$.

\section{Results and discussion}

Reaction of the 2-(arylazo)phenol ligands (HL) with tris-(acetylacetonato) ruthenium(III) afforded bis-complexes of type $\left[\mathrm{Ru}(\mathrm{acac})(\mathrm{L})_{2}\right]$ where two acetylacetonate ligands were replaced by the 2-(arylazo)phenolate ligands while one acetylacetonate is still retained. Formation of similar mixed ligand tris chelates, via incomplete dissociation of acetylacetonates from $\left[\mathrm{M}(\mathrm{acac})_{3}\right]$, is known for ruthenium [10] as well as other metals [11]. Elemental $(\mathrm{C}, \mathrm{H}, \mathrm{N})$ analytical data (Table 2$)$ of these $\left[\mathrm{Ru}(\mathrm{acac})(\mathrm{L})_{2}\right]$ complexes are in good agreement with their compositions. As acetylacetonate is a bidentate ligand and ruthenium is usually octahedrally coordinated, this indicates that the 2-(arylazo)phenolates are coordinated as bidentate ligands (as in $\mathbf{2}$ or $\mathbf{3}$ ). As the 2-(arylazo)phenolates are unsymmetrical bidentate ligands, the $\left[\mathrm{Ru}(\mathrm{acac})(\mathrm{L})_{2}\right]$ complexes may, in principle, exist in three different geometrical isomeric forms $(\mathbf{6}, 7$ and $\mathbf{8})$.

Molecular structure of a representative complex, viz. $\left[\mathrm{Ru}(\mathrm{acac})(\mathrm{an}-\mathrm{H})_{2}\right]$ has been solved by X-ray crystallography. The structure is shown in Fig. 1 and selected bond distances and angles are given in Table 3. The 1(phenylazo)naphtholate ligands are coordinated as bidentate N,O-donor ligand forming six-membered chelate rings (as in 2) with a bite angle of $\sim 90^{\circ}$. The coordination sphere around ruthenium is $\mathrm{N}_{2} \mathrm{O}_{4}$ which is slightly distorted from ideal octahedral geometry as reflected in the bond angles. The azo nitrogens occupied trans positions and the phenolate oxygens, cis positions. Therefore, structure determination shows that [Ru (acac) $\left.(\text { an- }-\mathrm{H})_{2}\right]$ has structure 6. The reason for the nitrogens to be in the trans position is probably steric in nature. A bulky phenyl group is linked to this nitrogen and rotation

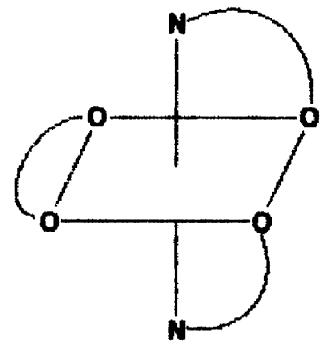

6

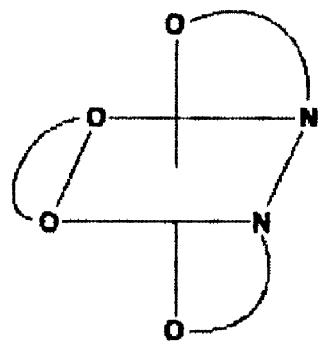

7

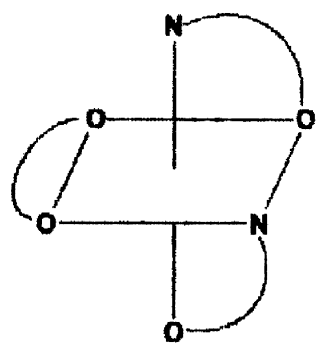

8

Table 2

Microanalytical, magnetic moment and electronic spectral data of the $\left[\mathrm{Ru}^{\mathrm{III}}(\mathrm{acac})(\mathrm{L})_{2}\right]$ complexes

\begin{tabular}{|c|c|c|c|c|c|}
\hline \multirow[t]{2}{*}{ Compound } & \multicolumn{3}{|c|}{ Microanalytical data ${ }^{\mathrm{a}}(\%)$} & \multirow{2}{*}{$\begin{array}{l}\mu_{\text {eff }} \\
(\mathrm{BM})\end{array}$} & \multirow[t]{2}{*}{ Electronic spectral data ${ }^{\mathrm{b}} \lambda(\mathrm{nm})\left(\varepsilon, \mathrm{M}^{-1} \mathrm{~cm}^{-1}\right)$} \\
\hline & $\mathrm{C}$ & $\mathrm{H}$ & $\mathrm{N}$ & & \\
\hline$\left[\mathrm{Ru}(\mathrm{acac})\left(\mathrm{ap}-\mathrm{OCH}_{3}\right)_{2}\right]$ & $57.8(58.1)$ & $4.8(4.8)$ & $8.0(8.2)$ & 1.93 & $\begin{array}{l}208(73400), 250^{\mathrm{c}}(31000), 345(17500), 427(14000), \\
731^{\mathrm{c}}(2400), 1220(214), 1550^{\mathrm{c}}(109)\end{array}$ \\
\hline$\left[\mathrm{Ru}(\mathrm{acac})\left(\mathrm{ap}-\mathrm{CH}_{3}\right)_{2}\right]$ & $60.5(60.9)$ & $5.0(5.1)$ & $8.5(8.6)$ & 1.87 & $\begin{array}{l}210(39000), 250^{\mathrm{c}}(25300), 316(17300), 422(11300), \\
680^{\mathrm{c}}(2300), 1260(221), 1671^{\mathrm{c}}(133)\end{array}$ \\
\hline$\left[\mathrm{Ru}(\mathrm{acac})(\mathrm{ap}-\mathrm{H})_{2}\right]$ & $60.4(59.8)$ & $4.9(4.7)$ & $9.1(9.0)$ & 1.90 & $\begin{array}{l}212(43300), 252^{\mathrm{c}}(2400), 302(20100), 426(11600), \\
684^{\mathrm{c}}(2100), 1336(193), 1700^{\mathrm{c}}(125)\end{array}$ \\
\hline$\left[\mathrm{Ru}(\mathrm{acac})(\mathrm{ap}-\mathrm{Cl})_{2}\right]$ & $53.1(53.8)$ & $3.7(3.9)$ & $8.0(8.1)$ & 1.85 & $\begin{array}{l}218(33200), 256^{\mathrm{c}}(21000), 294(19000), 436(11100), \\
706^{\mathrm{c}}(2100), 1230(151), 1618^{\mathrm{c}}(81)\end{array}$ \\
\hline$\left[\mathrm{Ru}(\mathrm{acac})\left(\mathrm{ap}-\mathrm{NO}_{2}\right)_{2}\right]$ & $52.6(52.2)$ & $4.0(3.8)$ & $11.9(11.8)$ & 1.89 & $\begin{array}{l}210(38400), 252^{\mathrm{c}}(22300), 320(20600), 453(9000), \\
744^{\mathrm{c}}(1400), 1300(83), 1700(57)\end{array}$ \\
\hline$\left[\mathrm{Ru}(\mathrm{acac})(\mathrm{an}-\mathrm{H})_{2}\right]$ & $64.4(64.0)$ & $4.2(4.2)$ & $8.3(8.1)$ & 1.90 & $\begin{array}{l}228(66200), 260^{c}(39100), 316(27300), 370(16700), \\
465(17000), 808^{c}(1900), 1435(346), 1900(293)\end{array}$ \\
\hline
\end{tabular}

${ }^{\text {a }}$ Calculated values are in parentheses.

${ }^{\mathrm{b}}$ In carbon tetrachloride solution.

'Shoulder. 
of this ring around the $\mathrm{C}-\mathrm{N}$ bond is allowed. With two such nitrogens in the cis positions (as in 7 and 8), severe steric interaction between these phenyl rings appears to be highly probable. The $\mathrm{Ru}-\mathrm{N}$ and $\mathrm{Ru}-\mathrm{O}$ distances are as usually observed in complexes of ruthenium(III) [4b]. The azo $\mathrm{N}-\mathrm{N}$ distances in $\left[\mathrm{Ru}(\mathrm{acac})(\mathrm{an}-\mathrm{H})_{2}\right]$ are longer than uncoordinated azo $(\mathrm{N}=\mathrm{N})$ distances [12]. However, they are similar to those observed in other structurally characterised azo complexes of trivalent ruthenium [7,13]. The phenolic $\mathrm{C}-\mathrm{O}$ distances are also quite normal $[4 \mathrm{~b}, 7]$. The bond distances in the $\mathrm{Ru}(\mathrm{acae})$ fragment compare well with those found in other complexes containing the $\mathrm{Ru}^{\mathrm{III}}$ (acac) moiety [14a,14b]. As the properties of all six $\left[\mathrm{Ru}(\mathrm{acac})(\mathrm{L})_{2}\right]$ complexes are similar (vide infra), the other five $\left[\mathrm{Ru}(\mathrm{acac})(\mathrm{L})_{2}\right]$ complexes are assumed to have a similar structure as $\left[\mathrm{Ru}(\mathrm{acac})(\mathrm{an}-\mathrm{H})_{2}\right]$.

Infrared spectra of the $\left[\mathrm{Ru}(\mathrm{acac})(\mathrm{L})_{2}\right]$ complexes are very similar. Each shows many vibrations of different intensities below $1700 \mathrm{~cm}^{-1}$. No attempt has been made for individual band assignment. However, comparison with the infrared spectrum of $\left[\mathrm{Ru}(\mathrm{acac})_{3}\right]$ shows the presence of additional vibrations in the spectra of $[\mathrm{Ru}$ $(\operatorname{acac})(\mathrm{L})_{2}$ ] complexes, which are indicative of the presence of 2-(arylazo)phenolate ligands. The $\left[\mathrm{Ru}(\mathrm{acac})(\mathrm{L})_{2}\right]$ complexes are soluble in common organic solvents like acetonitrile, acetone, hexane, carbon tetrachloride, etc., producing solutions with different shades of brown. Electronic spectra of these complexes were recorded in carbon tetrachloride solution. Spectral data are displayed in Table 2 and a selected spectrum is shown in Fig. 2. The spectral properties of all six complexes are similar. Each complex shows several intense absorptions in the visible region which are probably due to ligand-to-metal chargetransfer transitions. They also show two weak transitions in the near-IR region, the origin of which will be discussed below.

Magnetic susceptibility measurements show that the $\left[\mathrm{Ru}(\mathrm{acac})(\mathrm{L})_{2}\right]$ complexes are one-electron paramagnetic (Table 2), which is in accordance with the +3 state of ruthenium (low-spin $\mathrm{d}^{5}, S=1 / 2$ ) in these complexes. ESR spectra of the $\left[\mathrm{Ru}(\mathrm{acac})(\mathrm{L})_{2}\right]$ complexes were recorded in a 1:1 dichloromethane-toluene solution at $77 \mathrm{~K}$. A representative spectrum is shown in Fig. 3. Each complex shows a rhombic spectrum with three distinct g-values (Table 4). However, all the spectra may be regarded as pseudo-axial, consisting of two very closely spaced signals ( $g_{1}$ and $g_{2}$, rhombic component of $g_{\perp}$ ) and a rather isolated signal $\left(\mathrm{g}_{3}, \mathrm{~g}_{\|}\right.$in the axial case). Hence the axial distortion $(\Delta)$ that splits the $t_{2}$ level into a and $e$ components, is expected to be much larger than the rhombic distortion (V) which splits e. This splitting pattern is illustrated as an inset in Fig. 3. Spin-orbit coupling causes

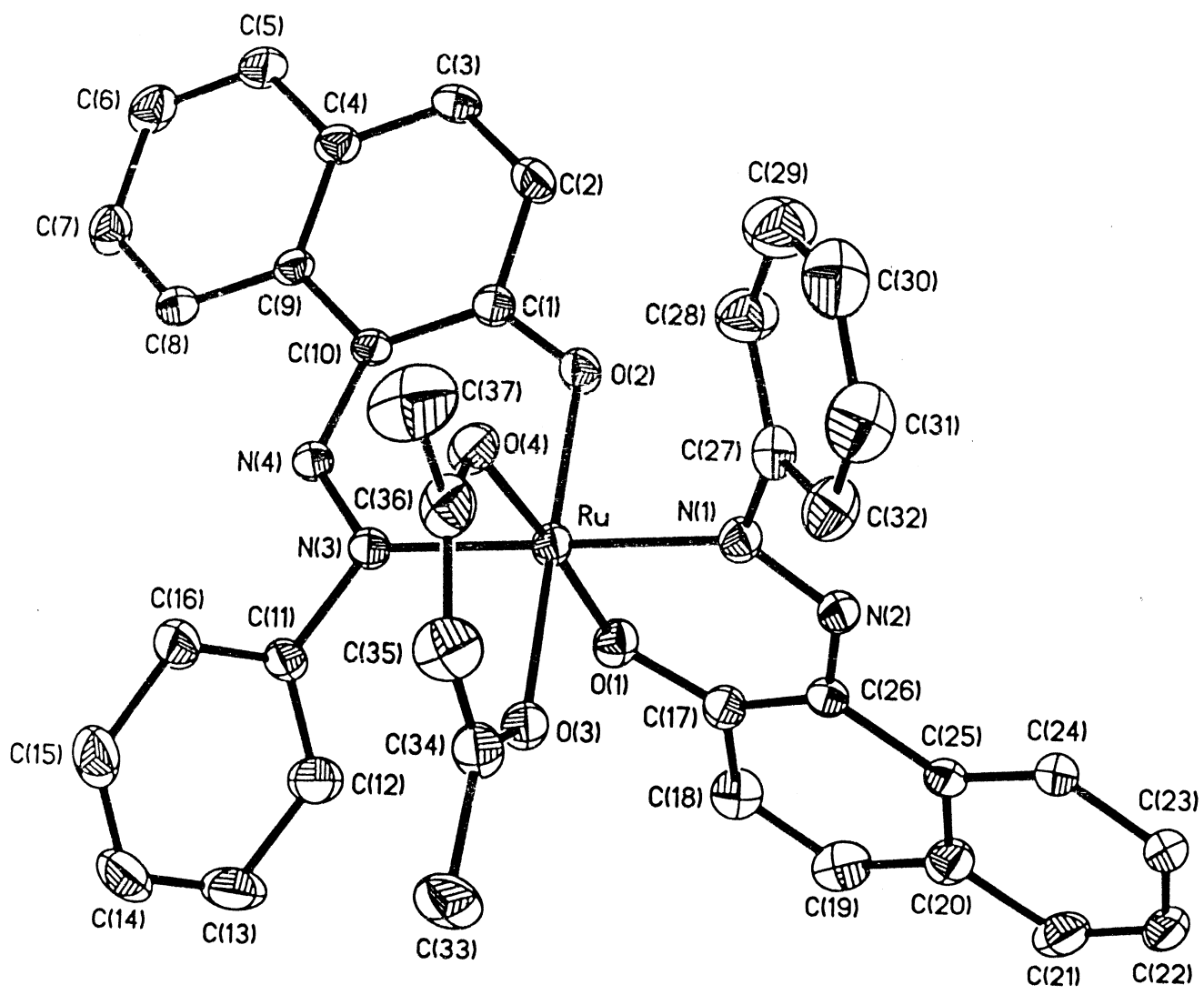

Fig. 1. View of the $\left[\mathrm{Ru}(\mathrm{acac})(\mathrm{an}-\mathrm{H})_{2}\right]$ molecule. 
Table 3

Selected bond distances and bond angles for $\left[\mathrm{Ru}(\mathrm{acac})(\mathrm{an}-\mathrm{H})_{2}\right]$

\begin{tabular}{|c|c|c|c|}
\hline \multicolumn{4}{|c|}{ Bond distances $(\AA)$} \\
\hline $\mathrm{Ru}-\mathrm{O}(1)$ & $1.973(2)$ & $\mathrm{C}(34)-\mathrm{O}(3)$ & 1.-277(4) \\
\hline $\mathrm{Ru}-\mathrm{O}(2)$ & $1.973(2)$ & $\mathrm{C}(34)-\mathrm{C}(35)$ & $1.380(6)$ \\
\hline $\mathrm{Ru}-\mathrm{O}(3)$ & $2.019(2)$ & $\mathrm{C}(35)-\mathrm{C}(36)$ & $1.382(6)$ \\
\hline $\mathrm{Ru}-\mathrm{O}(4)$ & $2.024(2)$ & $\mathrm{C}(36)-\mathrm{O}(4)$ & $1.280(4)$ \\
\hline $\mathrm{Ru}-\mathrm{N}(1)$ & $2.036(3)$ & & \\
\hline $\mathrm{Ru}-\mathrm{N}(3)$ & $2.037(3)$ & & \\
\hline \multicolumn{4}{|l|}{ Bond angles $\left({ }^{\circ}\right)$} \\
\hline $\mathrm{O}(2)-\mathrm{Ru}-\mathrm{O}(3)$ & $178.14(9)$ & & \\
\hline $\mathrm{O}(1)-\mathrm{Ru}-\mathrm{O}(4)$ & $175.63(10)$ & & \\
\hline $\mathrm{N}(1)-\mathrm{Ru}-\mathrm{N}(3)$ & 179.35(11) & & \\
\hline $\mathrm{O}(1)-\mathrm{Ru}-\mathrm{O}(2)$ & $95.64(10)$ & $\mathrm{O}(3)-\mathrm{Ru}-\mathrm{N}(1)$ & $88.76(10)$ \\
\hline $\mathrm{O}(1)-\mathrm{Ru}-\mathrm{O}(3)$ & $85.49(9)$ & $\mathrm{O}(4)-\mathrm{Ru}-\mathrm{N}(1)$ & $91.66(10)$ \\
\hline $\mathrm{O}(2)-\mathrm{Ru}-\mathrm{O}(4)$ & $88.38(10)$ & $\mathrm{O}(1)-\mathrm{Ru}-\mathrm{N}(3)$ & $89.48(10)$ \\
\hline $\mathrm{O}(3)-\mathrm{Ru}-\mathrm{O}(4)$ & $90.53(10)$ & $\mathrm{O}(2)-\mathrm{Ru}-\mathrm{N}(3)$ & $89.82(9)$ \\
\hline $\mathrm{O}(1)-\mathrm{Ru}-\mathrm{N}(1)$ & $90.08(10)$ & $\mathrm{O}(3)-\mathrm{Ru}-\mathrm{N}(3)$ & $91.68(9)$ \\
\hline $\mathrm{O}(2)-\mathrm{Ru}-\mathrm{N}(1)$ & $89.75(10)$ & $\mathrm{O}(4)-\mathrm{Ru}-\mathrm{N}(3)$ & $88.81(10)$ \\
\hline
\end{tabular}

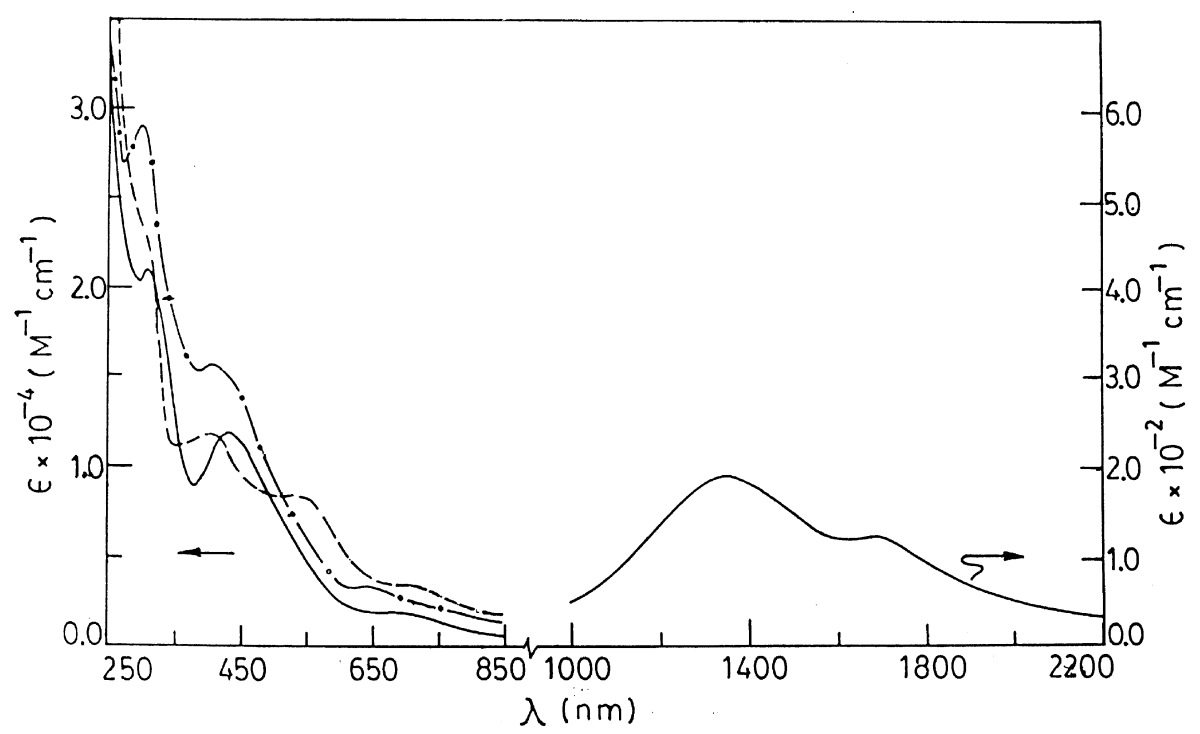

Fig. 2. Electronic spectra of $\left[\mathrm{Ru}^{\mathrm{III}}(\mathrm{acac})(\mathrm{ap}-\mathrm{H})_{2}\right]\left(-\right.$, in carbon tetrachloride solution), $\left[\mathrm{Ru}^{\mathrm{II}}(\mathrm{acac})(\mathrm{ap}-\mathrm{H})_{2}\right]^{-}(---$, in acetonitrile solution) and $\left[\mathrm{Ru}^{\mathrm{IV}}(\mathrm{acac})_{2}(\mathrm{ap}-\mathrm{H})_{2}\right]^{+}(-\cdot-$, in acetonitrile solution).

further changes in the energy gaps. Two electronic transitions (transition energies $\Delta E_{1}$ and $\Delta E_{2} ; \Delta E_{1}<\Delta E_{2}$ ) are therefore possible within these three levels. All the energy parameters have been computed (Table 4) using the observed g-values, g-tensor theory of low-spin $\mathrm{d}^{5}$ complexes $[15 \mathrm{a}, 15 \mathrm{~b}]$ and a reported method [16]. The axial distortion is indeed much larger than the rhombic one for all the six complexes. Taking the spin-orbit coupling constant $(\lambda)$ of complexed ruthenium(III) to be $1000 \mathrm{~cm}^{-1}$ [16], the $\Delta E_{1}$ and $\Delta E_{2}$ transitions are expected to appear near 6000 and $8000 \mathrm{~cm}^{-1}$, respectively. Both transitions were experimentally observed, at energies very close to the theoretically predicted values (Table 4), as two relatively weak absorptions (Table 2, Fig. 2). The ESR data analysis thus indicates that the $\left[\mathrm{Ru}(\mathrm{acac})(\mathrm{L})_{2}\right]$ complexes are distorted from ideal octahedral geometry, as also observed from the X-ray structure determination of $\left[\mathrm{Ru}(\mathrm{acac})(\mathrm{an}-\mathrm{H})_{2}\right]$.

Electron-transfer properties of the $\left[\mathrm{Ru}(\mathrm{acac})(\mathrm{L})_{2}\right]$ complexes were studied in acetonitrile solution (0.1 M TEAP) by cyclic voltammetry. Voltammetric data are presented in Table 5 and a selected voltammogram is shown in Fig. 4. Each complex shows two voltammetric responses, one oxidative response on the positive side of SCE and another reductive response on the negative side, which are respectively assigned to the ruthenium(III)ruthenium(IV) and ruthenium(III)-ruthenimn(II) couples (eqs. (1) and (2)). 
Table 4

ESR g-values ${ }^{\mathrm{a}}$ and derived parameters ${ }^{\mathrm{b}}$ of the $\left[\mathrm{Ru}(\mathrm{acac})(\mathrm{L})_{2}\right]$ complexes

\begin{tabular}{|c|c|c|c|c|c|c|c|}
\hline Compound & $\mathrm{g}_{1}$ & $\mathrm{~g}_{2}$ & $\mathrm{~g}_{3}$ & $\Delta / \lambda$ & $V / \lambda$ & $\Delta E_{1} / \lambda^{\mathrm{c}}$ & $\Delta E_{2} / \lambda^{\mathrm{c}}$ \\
\hline$\left[\mathrm{Ru}(\mathrm{acac})\left(\mathrm{ap}-\mathrm{OCH}_{3}\right)_{2}\right]$ & 2.141 & 2.117 & 1.938 & 6.76 & 0.87 & $6.25(6.45)$ & $7.50(8.20)$ \\
\hline$\left[\mathrm{Ru}(\mathrm{acac})\left(\mathrm{ap}-\mathrm{CH}_{3}\right)_{2}\right]$ & 2.152 & 2.120 & 1.938 & 6.83 & 1.11 & $6.23(5.98)$ & $7.66(7.94)$ \\
\hline$\left[\mathrm{Ru}(\mathrm{acac})(\mathrm{ap}-\mathrm{H})_{2}\right]$ & 2.152 & 2.124 & 1.940 & 6.93 & 1.00 & $6.37(5.88)$ & $7.73(7.48)$ \\
\hline$\left[\mathrm{Ru}(\mathrm{acac})(\mathrm{ap}-\mathrm{Cl})_{2}\right]$ & 2.166 & 2.114 & 1.938 & 6.94 & 1.85 & $6.02(6.18)$ & $8.08(8.13)$ \\
\hline$\left[\mathrm{Ru}(\mathrm{acac})\left(\mathrm{ap}-\mathrm{NO}_{2}\right)_{2}\right]$ & 2.141 & 2.114 & 1.941 & 6.95 & 1.05 & $6.37(5.88)$ & $7.77(7.69)$ \\
\hline$\left[\mathrm{Ru}(\mathrm{acac})(\mathrm{an}-\mathrm{H})_{2}\right]$ & 2.161 & 2.117 & 1.939 & 6.93 & 1.56 & $6.14(5.26)$ & $7.95(6.97)$ \\
\hline
\end{tabular}

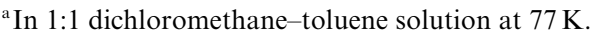

${ }^{\mathrm{b}}$ Spin-orbit coupling constant $(\lambda)$ for complexed $\mathrm{Ru}(\mathrm{III})$ is $\sim 1000 \mathrm{~cm}^{-1}$.

${ }^{\mathrm{c}}$ The experimentally observed values (see Table 2 ) are given in parentheses.

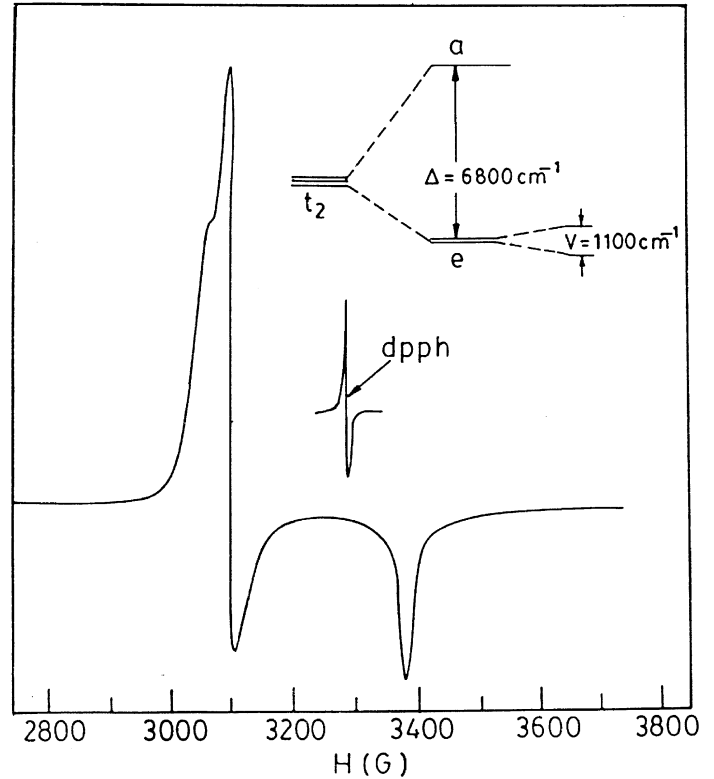

Fig. 3. ESR spechm of $\left[\mathrm{Ru}(\mathrm{acac})\left(\mathrm{ap}-\mathrm{CH}_{3}\right)_{2}\right]$ in $1: 1$ dichloromethane:toluene at $77 \mathrm{~K}$.

Table 5

Cyclic voltammetric data ${ }^{\mathrm{a}}$

\begin{tabular}{|c|c|c|}
\hline \multirow[t]{2}{*}{ Compound } & \multicolumn{2}{|c|}{$E_{1 / 2}(\mathrm{~V})\left(\Delta E_{\mathrm{p}}, \mathrm{mV}\right)$} \\
\hline & $\mathrm{Ru} \mathrm{II}^{\mathrm{II}} \mathrm{R} \mathrm{u}^{\mathrm{III}}$ & $\mathrm{Ru}^{\mathrm{III}} / \mathrm{Ru}^{\mathrm{IV}}$ \\
\hline$\left[\mathrm{Ru}(\mathrm{acac})\left(\mathrm{ap}-\mathrm{OCH}_{3}\right)_{2}\right]$ & $-0.52(60)$ & $0.87(70)$ \\
\hline$\left[\mathrm{Ru}(\mathrm{acac})\left(\mathrm{ap}-\mathrm{CH}_{3}\right)_{2}\right]$ & $-0.50(70)$ & $0.89(60)$ \\
\hline$\left[\mathrm{Ru}(\mathrm{acac})(\mathrm{ap}-\mathrm{H})_{2}\right]$ & $-0.47(60)$ & $0.91(60)$ \\
\hline$\left[\mathrm{Ru}(\mathrm{acac})(\mathrm{ap}-\mathrm{Cl})_{2}\right]$ & $-0.41(70)$ & $0.95(60)$ \\
\hline$\left[\mathrm{Ru}(\mathrm{acac})\left(\mathrm{ap}-\mathrm{NO}_{2}\right)_{2}\right]$ & $-0.31(60)$ & $1.03(70)$ \\
\hline$\left[\mathrm{Ru}(\mathrm{acac})(\mathrm{an}-\mathrm{H})_{2}\right]$ & $-0.24(60)$ & $0.83(60)$ \\
\hline
\end{tabular}

${ }^{a}$ Conditions: solvent, acetonitrile; supporting electrolyte, TEAP $(0.1 \mathrm{M})$; working electrode, platinum; auxiliary electrode, platinum: reference electrode, SCE: solute concentration, $\sim 10^{-3} \mathrm{M}$; $E_{1 / 2}=0.5\left(E_{\mathrm{pa}}+E_{\mathrm{pc}}\right)$, where $E_{\mathrm{pa}}$ and $E_{\mathrm{pc}}$ are anodic and cathodic peak potentials; $\Delta E_{\mathrm{p}}=E_{\mathrm{pa}}-E_{\mathrm{pc}}$; scan rate $50 \mathrm{mV} \mathrm{S}^{-1}$.

$$
\begin{aligned}
& {\left[\mathrm{Ru}^{\mathrm{III}}(\mathrm{acac})(\mathrm{L})_{2}\right] \rightleftharpoons\left[\mathrm{Ru}^{\mathrm{IV}}(\mathrm{acac})(\mathrm{L})_{2}\right]^{+}+\mathrm{e}^{-}} \\
& {\left[\mathrm{Ru}^{\mathrm{III}}(\mathrm{acac})(\mathrm{L})_{2}\right]+\mathrm{e}^{-} \rightleftharpoons\left[\mathrm{Ru}^{\mathrm{II}}(\mathrm{acac})(\mathrm{L})_{2}\right]^{-}}
\end{aligned}
$$

Both responses are reversible with a peak-to-peak separation of $60-70 \mathrm{mV}$. The one-electron nature of these couples are established by constant potential coulometry (vide infra). It may be noted here that the ruthenium(III)ruthenium(IV) and ruthenium(III)-ruthenium(II) potentials of these $\left[\mathrm{Ru}(\mathrm{acac})(\mathrm{L})_{2}\right]$ complexes are much lower than those in the $\left[\mathrm{Ru}(\mathrm{bpy})(\mathrm{L})_{2}\right] \quad\left(\mathrm{bpy}=2,2^{\prime}\right.$-bipyridine) complexes [8c], which is due to the hard nature of the acetylacetonate oxygens compared to the soft nitrogens in bpy.

Potentials of both the ruthenium(III)-ruthenium(II) and ruthenimn(III)-ruthenium(IV) couples in these $\left[\mathrm{Ru}(\mathrm{acac})(\mathrm{L})_{2}\right] \quad(\mathrm{L}=$ the 2-(arylazo)-4-methylphenolate ligands) complexes are found to be sensitive to the nature of the substituent $\mathrm{R}$. With increasing electron-withdrawing character of $\mathrm{R}$, the formal potentials $\left(E_{1 / 2}\right)$ of both couples increase. The plot of the $E_{1 / 2}$ values vs $2 \sigma$ (where $\sigma$ is the Hammett constant of R [17]) are linear (Fig. 5). The slope of these lines, which is known as the reaction constant $\rho[18]$ and is a measure of the sensitivity of $E_{1 / 2}$ with $\mathrm{R}$, is 0.08 for the ruthenium(III)ruthenium(IV) couple and 0.10 for the ruthenium(III)ruthenium(II) couple. It is clear from these plots that the ruthenium(III)-ruthenium(II) couple is more influenced by $\mathrm{R}$ compared to the ruthenium(III)-ruthenium(IV) couple. It is also interesting to note that a single substituent, which is six bonds away from the electroactive metal center, can influence the metal-centred redox potentials in a predictable manner.

From the reversible nature of both ruthenium(III)ruthenium(IV) and ruthenium(III)-ruthenium(II) couples, it appeared that both the oxidized species, i.e. $\left[\mathrm{Ru}^{\mathrm{IV}}(\mathrm{acac})(\mathrm{L})_{2}\right]^{+}$and the reduced species, i.e. $\left[\mathrm{Ru}^{\mathrm{II}}\right.$ $\left.(\operatorname{acac})(\mathrm{L})_{2}\right]^{-}$, might be stable on longer time scales. To investigate this, $\left[\mathrm{Ru}(\mathrm{acac})(\mathrm{L})_{2}\right]$ was coulometrically oxidized near $1.2 \mathrm{~V}$ vs SCE. The oxidations have been smooth and quantitative with $n \sim 1$ [ $n$ (number of electron transfer) $=Q_{\mathrm{f}} / Q_{\mathrm{c}}$, where $Q_{\mathrm{c}}=$ calculated Coulomb count 


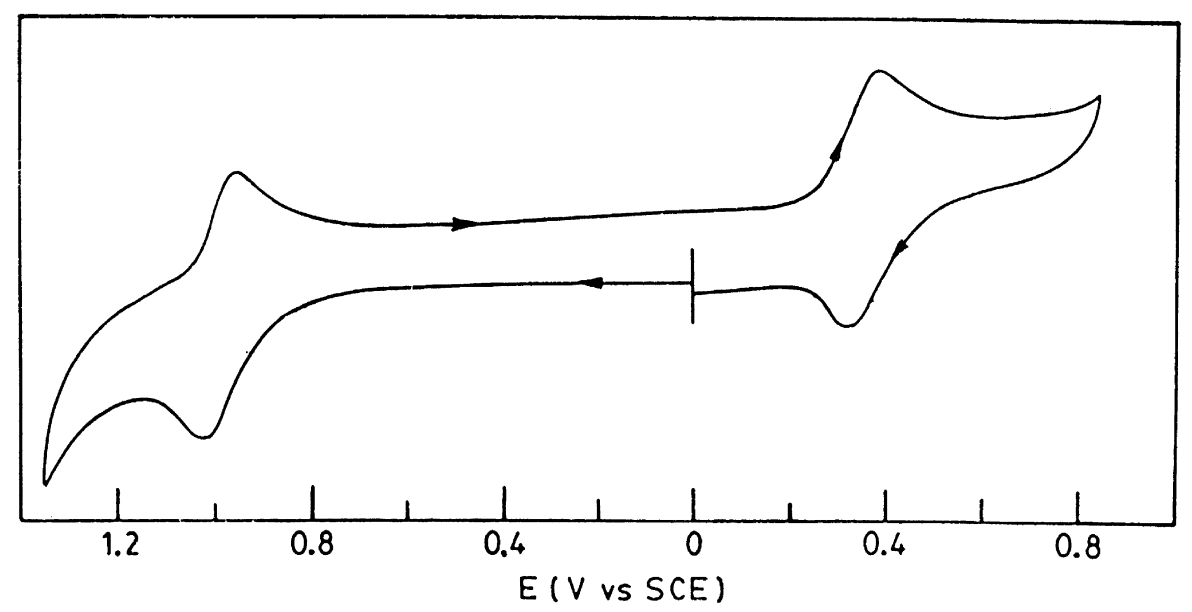

Fig. 4. Cyclic voltammogram of $\left[\mathrm{Ru}(\mathrm{acae})\left(\mathrm{ap}-\mathrm{NO}_{2}\right)_{2}\right]$ in acetonitrile solution $\left(0.1 \mathrm{M}\right.$ TEAP) at a scan rate of $50 \mathrm{mV} \mathrm{S}^{-1}$.

Table 6

Electronic spectral data $a^{\mathrm{a}}$ of the $\left[\mathrm{Ru}^{\mathrm{II}}(\mathrm{acac})(\mathrm{L})_{2}\right]^{-}$and $\left[\mathrm{Ru}^{\mathrm{IV}}(\mathrm{acac})(\mathrm{L})_{2}\right]^{+}$complexes $\lambda(\mathrm{nm})\left(\varepsilon, \mathrm{M}^{-1} \mathrm{~cm}^{-1}\right)$

\begin{tabular}{|c|c|c|}
\hline $\mathrm{L}$ & {$\left[\mathrm{Ru}^{\mathrm{II}}(\mathrm{acac})(\mathrm{L})_{2}\right]^{-}$} & {$\left[\mathrm{Ru}^{\mathrm{IV}}(\mathrm{acac})(\mathrm{L})_{2}\right]^{+}$} \\
\hline ap- $\mathrm{OCH}_{3}$ & $230(90700), 320^{\mathrm{b}}(22400), 404(17400), 525(11800), 704^{\mathrm{b}}(5300)$ & $\begin{array}{l}212(46800), 250^{\mathrm{b}}(29000), 344(16600), 424(14500), 680^{\mathrm{b}} \\
(2300)\end{array}$ \\
\hline ap- $\mathrm{CH}_{3}$ & $232(106100), 308^{\mathrm{b}}(25100), 400(16400), 530(11700), 700^{\mathrm{b}}(5600)$ & $\begin{array}{l}212(46800), 252^{\mathrm{b}}(28200), 316(19500), 420(13400), 652^{\mathrm{b}} \\
(2600)\end{array}$ \\
\hline ap-H & $225(190000), 304^{\mathrm{b}}(22200), 408(11400), 540(8200), 708^{\mathrm{b}}(3600)$ & $\begin{array}{l}212(73100), 250^{\mathrm{b}}(39400), 304(29000), 424(15600), 656^{\mathrm{b}} \\
(3300)\end{array}$ \\
\hline ap-Cl & $228(10400), 284^{\mathrm{b}}(38600), 396(17500), 532(15300), 704^{\mathrm{b}}(7300)$ & $\begin{array}{l}212(56200), 252^{\mathrm{b}}(31500), 300(24300), 424(15000), 680^{\mathrm{b}} \\
(3700)\end{array}$ \\
\hline ap- $-\mathrm{NO}_{2}$ & 230 (102600), 292 (24200), 400 (13500), $548(8500), 740^{\mathrm{b}}(4300)$ & $\begin{array}{l}212(62700), 248(43400), 296(36500), 440^{\mathrm{b}}(17100), 732^{\mathrm{b}} \\
(3800)\end{array}$ \\
\hline an-H & 232 (93200), 304 (33000), 380 (22500), $556(17200), 720^{\mathrm{b}}(7300)$ & $\begin{array}{l}216(60000), 250^{\mathrm{b}}(37900), 300^{\mathrm{b}}(16700), 364(16700), 460 \\
(15400), 756^{\mathrm{b}}(1900)\end{array}$ \\
\hline
\end{tabular}

${ }^{\mathrm{a}}$ In acetonitrile solution.

${ }^{\mathrm{b}}$ Shoulder.

and $Q_{\mathrm{f}}=$ observed Coulomb count], affording yellowishbrown solutions of $\left[\mathrm{Ru}^{\mathrm{IV}}(\mathrm{aeac})(\mathrm{L})_{2}\right]^{+}$. These solutions show identical cyclic voltammograms as their respective precursors, the only exception being the ruthenium(III)ruthenium(IV) couple appears as a reductive response. The same oxidations were achieved chemically by a solution of $\mathrm{Ce}^{4+}$ in $1 \mathrm{M} \mathrm{HClO}_{4}$. Electronic spectra of the $\left[\mathrm{Ru}^{\mathrm{IV}}(\mathrm{acac})(\mathrm{L})_{2}\right]^{+}$complexes in acetonitrile solution show several intense absorptions in the visible and $U V$ region (Table 6, Fig. 2). Chemical or electrochemical reduction of the oxidized complexes gives the $\left[\mathrm{Ru}^{\mathrm{III}}(\mathrm{acac})(\mathrm{L})_{2}\right] \mathrm{com}$ plexes, identified by their characteristic electronic spectra.

Coulometric reduction of the $\left[\mathrm{Ru}^{\mathrm{III}}(\mathrm{acac})(\mathrm{L})_{2}\right] \mathrm{com}-$ plexes near $-0.6 \mathrm{~V}$ vs SCE quantitatively $(n \sim 1)$ afforded pink (blue for $\mathrm{L}=\mathrm{an}-\mathrm{H})$ solutions of $\left[\mathrm{Ru}^{\mathrm{II}}\right.$ $\left.(\operatorname{acac})(\mathrm{L})_{2}\right]^{-}$. The reduced solutions show identical cyclic voltammograms [besides that the ruthenium(III) ruthenium(II) couple appears as an oxidative response] as their respective precursors. The same pink (or blue) solutions were also generated by chemical reduction of $\left[\mathrm{Ru}^{\mathrm{III}}(\mathrm{acac})(\mathrm{L})_{2}\right]$ with hydrazine. Electronic spectra of the bivalent complexes, recorded in acetonitrile solution, show intense transitions in the visible and UV region (Table 6, Fig. 2). Coulometric or chemical (by hydrogen peroxide) oxidation of the pink (or blue) solutions gives back original solutions of the respective $\left[\mathrm{Ru}^{\mathrm{III}}(\mathrm{acac})(\mathrm{L})_{2}\right]$ complexes. The above interconversions indicate that both the ruthenium(III)-ruthenium(IV) and ruthenium(III)ruthenium(II) couples are chemically reversible.

Addition of excess hydrazine to $\left[\mathrm{Ru}^{\mathrm{III}}(\mathrm{acac})(\mathrm{L})_{2}\right]$, though initially causes instantaneous reduction to $\left[\mathrm{Ru}^{\mathrm{II}}\right.$ $\left.(\operatorname{acac})(\mathrm{L})_{2}\right]^{-}$, slowly brings about a secondary chemical transformation producing deep pink solutions which show an intense absorption near $530 \mathrm{~nm}\left(\epsilon \sim 50,000 \mathrm{M}^{-1}\right.$ $\mathrm{cm}^{-1}$ ). Though the exact composition of these species is not clear yet, it appears that the coordinated acac has underwent Schiff-base condensation with hydrazine yielding stable complexes of bivalent ruthenium. Further 

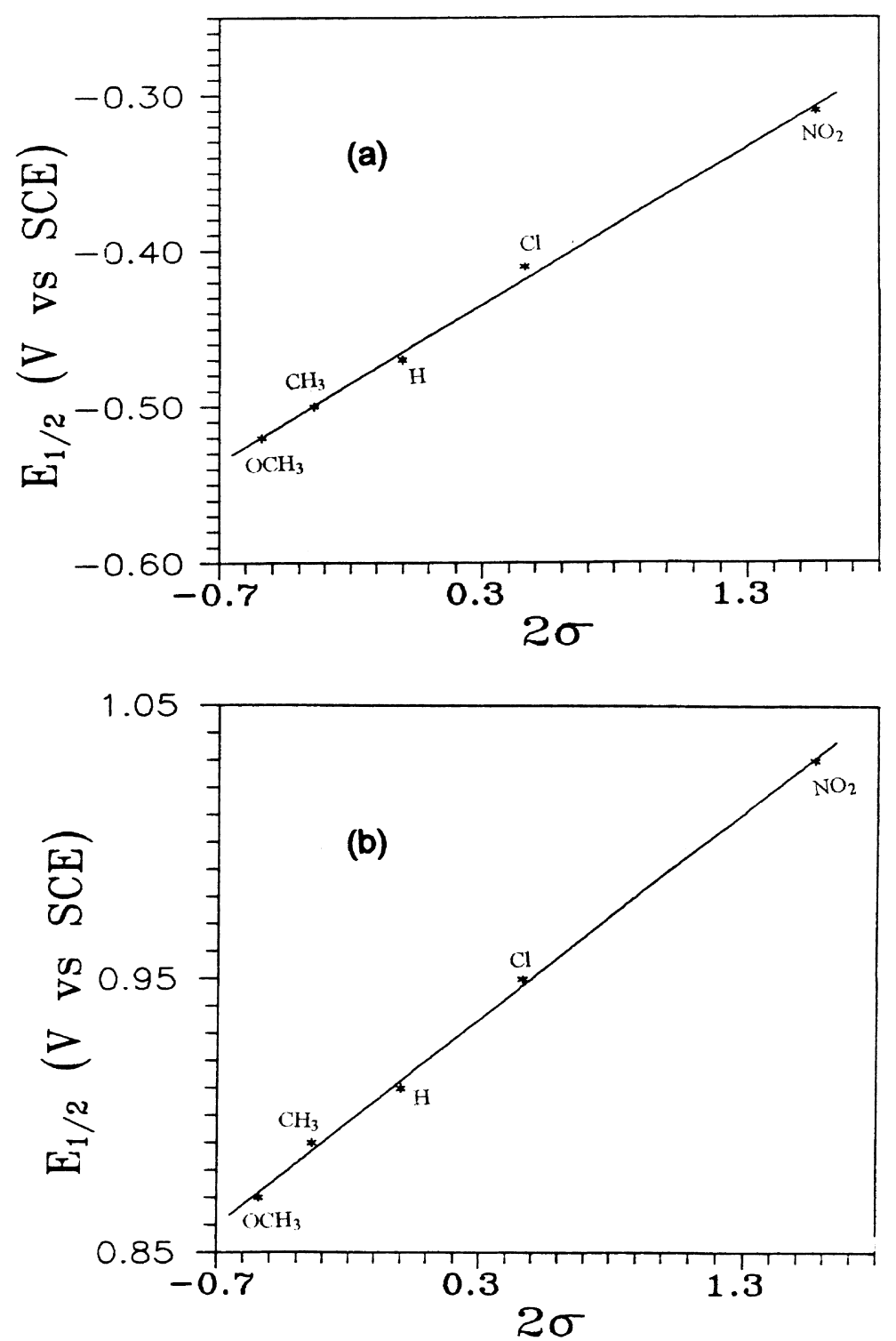

Fig. 5. Least-squares plot of $E_{1 / 2}$ values of (a) $\mathrm{Ru}^{\mathrm{II}} / \mathrm{Ru}^{\mathrm{III}}$ couple vs $2 \sigma$ and (b) $\mathrm{Ru}^{\mathrm{III}} / \mathrm{Ru}^{\mathrm{IV}}$ couple vs $2 \sigma$.

characterization of these species is currently under progress.

\section{Conclusions}

This study shows that in spite of coordination by two azo nitrogens, coordination by phenolate oxygen is more effective in stabilising higher oxidation states of ruthenium. The possibility of using the $\left[\mathrm{Ru}\left(\mathrm{D}_{2}\right)(\mathrm{L})_{2}\right]$ complexes as starting materials for the synthesis of complexes of type $\left[R u\left(D_{2}\right)(L)_{2}\right]$, where $D_{2}$ is either a bidentate ligand or two monodentate ligands, is under scrutiny. Template Schiff base condensation at the coordinated acetylacetonate ligand is also under investigation.

\section{Acknowledgements}

Financial support from the Council of Scientific and Industrial Research, New Delhi [01(1408)/96/EMR-II], India, is gratefully acknowledged. Our sincere thanks go to Professor Animesh Chakravorty (Indian Association for the Cultivation of Science, Calcutta), Professor Gurunath Mukherjee (Calcutta University) and Dr. Rupendranath Banerjee (Jadavpur University) for their kind help.

\section{References}

[1] (a) Hage R. Coord Chem Rev 1991;111:161; (b) Wallendael SV, Rillema DP. Coord Chem Rev 1991;111:297; (c) Lever ABP, Mausi 
H, Matealfc RA, Stufkens DJ, Dodsworth ES, Auburn PR. Coord Chem Rev 1993;125:317; (d) Wong WT. Coord Chem Rev 1994;131:45; (e) Haga M, Ali Md M, Maegawa M, Nozaki K, Yoshimura A, Ohno T. Coord Chem Rev 1994;132:99; (f) Constable EC, Housecroft CE. Coord Chem Rev 1994;134(Part 2):133; (g) Chan S, Wong WT. Coord Chem Rev 1995;138:219; (h) Richmond MG. Coord Chem Rev 1995;141:63; (i) Chen L, Poe AJ. Coord Chem Rev 1995;143:265; (j) Wong WY, Wong WT. Coord Chem Rev 1995;146(Part B):307.

[2] (a) Pramanik NC, Bhattacharya S. J Chem Res (S) 1997;98; (b) Pramanik NC, Bhattacharya S. Trans Met Chem 1997;22:524; (c) Basuli F, Peng SM, Bhattacharya S. Inorg Chem 1997;36:5645; (d) Pramanik NC, Pramanik K, Ghosh P, Bhattacharya S. Polyhedron 1998; 17:1525.

[3] (a) Krause RA, Krause K. Inorg Chem 1980;19:2600; (b) Goswami S, Chakravarty AR, Chakravorty A. Inorg Chem 1981;20:2246.

[4] (a) Lahiri GK, Bhattacharya S, Ghosh BK, Chakravorty A. Inorg Chem 1987;26:4324; (b) Bag N, Lahiri GK, Bhattacharya S, Falvello LR, Chakravorty A. Inorg Chem 1988;27:4396; (c) Bhattacharya S, Boone SR, Fox GA, Pierpont CG. J Am Chem Soc 1990;112:1088; (d) Bhattacharya S. Polyhedron 1993;12:235; (e) Bhattacharya S. Polyhedron 1994;13:451; (f) Chakravarty J, Bbattacharya S. Polyhedron 1996;15:257; (g) Pramanik NC, Bbattacharya S. Polyhedron 1997;16:1755.

[5] (a) Haendur HM, Smith GMP. J Am Chem Soc 1940;62:1669; (b) Ueno K. J Am Chem Soc 1957;79:3066; (c) Jarvis, JAJ. Acta Cryst 1961;14:961; (d) Price R. J Am Chem Soc A 1969;1296; (e) Kalia KC. Indian J Chem 1970;8:1035; (f) Dyachenko OA, Atovmyan L, Aldoshin SM. Chem Soc Chem Commun 1975; 105; (g) Marov IN, Gambarov DG, Belyaeva VK, Guseinov AG, Sokolov AB. Russ J Inorg Chem 1948;2910:1452; (h) Sinha CR, Bandopadhyay
D, Chakravorty A. J Chem Soc Chem Commun 1988, 468; (i) Bhawmik R, Biswas H, Bandopadhyay P. J Org Met Chem 1995;81:498; (j) Callis CF, Nielsen NC, Bailar Jr JC. J Am Chem Soc 1952; $74: 3461$.

[6] Basuli F, Peng SM, Bhattacharya S. Polyhedron 1998 Vol. 17, in press.

[7] Lahiri GK, Bhattacharya S, Mukherjee S, Mukherjee M, Chakravorty A. Inorg Chem 1987;26:3359.

[8] Benson EP, Legg JI. Inorg Chem 1981;20:2504; (b) Chakravarty J, Bhattacharya S. Polyhedron 15;1047; (c) Sinha PK, Chakravarty J, Bhattacharya S. Polyhedron 1996;15:2931; (d) Pramanik NC, Bhattacharya S. Polyhedron 1997;16:3047.

[9] Endo A, Watanbe M, Hayashi S, Shimizu K, Sato GP. Bull Chem Soc Jpn 1978;51:800.

[10] Bardwell DA, Black D, Jeffery JC, Schatz E, Ward MD. J Chem Soc Dalton Trans 1993;2321.

[11] Yamaguchi K, Sawyer DT. Inorg Chem 1985;24:971.

[12] Seal A, Roy S. Acta Cryst C 1984;40:929.

[13] Manivannan V, Dirghangi BK, Pal CK, Chakravorty A. Inorg Chem 1997;36:1526.

[14] (a) Chao GKJ, Sime RL, Sime RJ. Acta Cryst B 1973;29:2845; (b) Hasegawa T, Lau TC, Taube H, Schaefer WP. Inorg Chem 1991;30:2921.

[15] (a) Bleany B, O'Brien, MCM. Proc Phys Soc London B 1956;69:1216; (b) Griffith JS. The theory of transition metal ions. London: Cambridge University Press, 1961. p. 364.

[16] Bhattacharya S, Chakravorty A. Proc Indian Acad Sci Chem Sci 1985;95:159.

[17] Hammett LP. Physical Organic Chemistry, 2nd edn. New York: McGraw Hill, 1970.

[18] Mukherjee RN, Rajan OA, Chakravorty A. Inorg Chem 1982;21:785. 